\title{
Seasonal and distributional patterns of seabirds along the Aleutian Archipelago
}

\author{
Martin Renner ${ }^{1, *}$, George L. Hunt Jr. ${ }^{1}$, John F. Piatt $^{2}$, G. Vernon Byrd ${ }^{3}$ \\ ${ }^{1}$ School of Aquatic and Fishery Sciences, University of Washington, Box 355020, Seattle, Washington 98195, USA \\ ${ }^{2}$ Alaska Science Center, U. S. Geological Survey, 1011 E. Tudor Rd, Anchorage, Alaska 99503, USA \\ ${ }^{3}$ Alaska Maritime National Wildlife Refuge, 95 Sterling Highway, Suite 1, Homer, Alaska 99603, USA
}

\begin{abstract}
The Aleutian Archipelago is of global importance to seabirds during the northern summer, but little is known about seabird use of these waters during winter. We compare summer and winter abundances of seabirds around 3 islands: Buldir in the western, Kasatochi in the central, and Aiktak in the eastern Aleutians. The density of combined seabird biomass in nearshore marine waters was higher in summer than in winter at Buldir and Kasatochi, but was higher in winter at Aiktak, despite the departure of abundant migratory species. Comparing foraging guilds, we found that only piscivores increased at the western and central sites in winter, whereas at the eastern site several planktivorous species increased as well. The only planktivore remaining in winter at the central and western sites in densities comparable to summer densities was whiskered auklet Aethia pygmaea. Crested auklet Aethia cristatella and thick-billed murre Uria lomvia showed the greatest proportional winter increase at the eastern site. The seasonal patterns of the seabird communities suggest a winter breakdown of the copepod-based food web in the central and western parts of the archipelago, and a system that remains rich in euphausiids in the eastern Aleutians. We suggest that in winter crested auklets take the trophic role that short-tailed shearwaters Puffinus tenuirostris occupy during summer. We hypothesize that advection of euphausiids in the Aleutian North Slope Current is important for supporting the high biomass of planktivores that occupy the Unimak Pass region on a year-round basis.
\end{abstract}

KEY WORDS: Aleutian North Slope Current - Euphausiids · Indicator species - Seabird biomass Resale or republication not permitted without written consent of the publisher

\section{INTRODUCTION}

Many seabird and commercial fish species depend directly on pelagic zooplankton. Therefore, seasonal changes in zooplankton availability will have profound effects on the distribution and abundance of these consumers. Annual mean zooplankton abundance in the surface layer in Aleutian Archipelago waters is predicted to be the highest in the Northern Hemisphere (Nakata et al. 2004). Not surprisingly then, aggregations of planktivorous seabirds in waters of the Aleutian Archipelago are of global significance.

In contrast to the considerable amounts of information available on the distribution of zooplankton, fish, and seabirds in Aleutian waters during spring and summer (Hunt et al. 1998, Byrd et al. 2005, Coyle 2005,
Jahncke et al. 2005, Logerwell et al. 2005), little is known about Aleutian zooplankton or seabird distribution and abundance patterns in winter. The physical processes bringing plankton onto the continental shelf during summer (Hunt et al. 1998) are probably still active over the winter, since current flows do not show major changes between winter and summer (Overland et al. 1994). However, the large Neocalanus spp. copepods, which dominate the mesozooplankton fauna of the central and western Aleutians (Coyle 2005) and are important prey for seabirds (Hunt et al. 1998, Jahncke et al. 2005), overwinter in diapause after descending to a depth of $>250 \mathrm{~m}$ (Miller \& Clemons 1988), where they are unavailable to seabirds.

Euphausiids form large aggregations and are important prey of commercially valuable fish, marine mam- 
mals, and seabirds (Tanasichuk 1999, Jahncke et al. 2005). Adult euphausiid stages come to the sea surface primarily at night and descend to depths $>100 \mathrm{~m}$ during the day, but upwelling waters can flush them to the surface, making them available to seabirds during the day (Coyle et al. 1992, Hunt et al. 1998, Ladd et al. 2005).

Major habitat features characterizing waters of the Aleutian Archipelago are bottom topography and current systems. Synthesizing the information on oceanography, plankton, fish, and seabirds, Piatt \& Springer (2007) identified 3 major eco-regions along the Aleutian Islands, with boundaries around Samalga Pass (Hunt \& Stabeno 2005) and Amchitka Pass (Logerwell et al. 2005). Recent seabird surveys have been conducted in nearshore waters in both summer and winter at sites in each of these eco-regions (eastern, central, and western Aleutians), and these provide a basis for comparing geographic differences in seasonal bird assemblages. Seabird distribution is likely to be driven by prey availability, particularly in winter when the birds are not constrained by having to return to a breeding site.

Here, we evaluate the seasonal differences in the biomass of piscivorous and planktivorous seabirds in these broadly distinct oceanographic regions in the Aleutians, using seabirds as indicators of differences in marine food webs. We expect that the differences in food webs would be reflected in changes in seabird

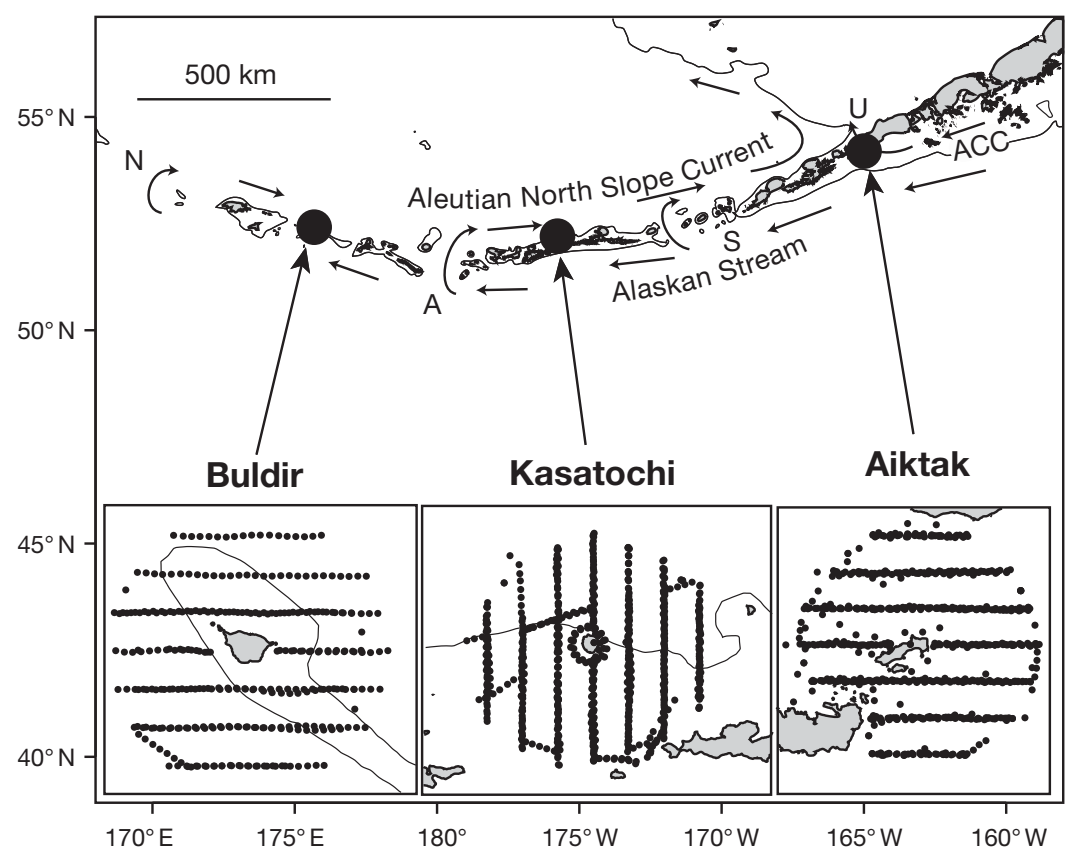

Fig. 1. Locations of Buldir, Kasatochi, and Aiktak Islands within the Aleutian Islands. Also shown are the $200 \mathrm{~m}$ isobath and the major current systems (ACC: Alaska Coastal Current) and passes (N: Near Strait; A: Amchitka Pass; S: Samalga Pass; U: Unimak Pass). Only observations within 10 nautical miles of the respective islands were used (black dots on inserts) species composition and biomass. Furthermore, if Samalga Pass is a distinctive ecological boundary (Hunt \& Stabeno 2005), we predict that the central and western Aleutian sites would be similar and distinct from the eastern Aleutian site. We draw inferences concerning the availability of plankton fauna in the region during winter, and hypothesize as to why the seasonal changes in the avifauna of the eastern Aleutians should differ so markedly from the patterns seen in the central and western Aleutians.

\section{MATERIALS AND METHODS}

Study area. Three major ocean current systems affect marine food webs in the Aleutian Archipelago (Overland et al. 1994, Stabeno et al. 1999). The Alaska Coastal Current is a relatively fresh, warm, nutrient-depleted current (Mordy et al. 2005). It flows nearshore from east to west over the continental shelf of the Alaska Peninsula to the eastern Aleutians, where it moves into the eastern Bering Sea through passes from Unimak Pass to Samalga Pass (see Fig. 1; Ladd et al. 2005). The Alaskan Stream, which is colder and richer in nutrients, parallels the Alaska Coastal Current offshore, seaward of the continental shelf, through the western Gulf of Alaska and eastern Aleutians, but flows close to the islands farther west (Hunt \& Stabeno 2005). The Alaskan Stream also carries more oceanic zooplankton taxa, especially Neocalanus, than the more neritic Alaska Coastal Current (Coyle \& Pinchuk 2005). A significant proportion of the Alaskan Stream passes through Amukta and Amchitka Passes (Stabeno et al. 2005). An extension of the Alaskan Stream continues westward past Buldir Island and then enters the Bering Sea through Near Strait (Stabeno et al. 1999). As the Alaskan Stream flows north through deep passes west of Samalga Pass, it turns east and combines with the Aleutian North Slope Current, which flows eastward along the north side of the Aleutian chain (Reed \& Stabeno 1999, Stabeno et al. 2005).

Eddies and tidal flows are superimposed over the large-scale patterns (Stabeno et al. 1999) and cause finescale habitat diversity. Tidal currents dominate the water flux within the passes with a net flow from the Pacific into the Bering Sea (Stabeno et al. 2002). Advection at the sills concentrates zooplankton in shallow depth strata, where they become accessible to 
seabirds (Hunt et al. 1998). This mechanism is particularly effective in shallow passes (Jahncke et al. 2005, Ladd et al. 2005). For some seabird species, colony distribution too is related to proximity to passes (Byrd et al. 2005). Sea temperatures are another major characteristic of marine habitats, but there are no clear spatial trends in sea surface temperature within Aleutian waters (Luchin et al. 1999).

Samalga Pass, in the eastern Aleutian Archipelago, marks an important transition in the Aleutian Archipelago ecosystem, with strong differences in bathymetry, meteorology, zooplankton, fish, benthic fauna, and avifauna to the east and west of there (Hunt \& Stabeno 2005). Eastern passes are less saline and warmer than the central passes, suggesting a more neritic environment in the east (Coyle 2005). Similarly, zooplankton species composition changes from dominantly neritic genera in the east to mostly oceanic genera in the west (Coyle 2005). During the breeding season, planktivorous seabirds, such as auklets and storm-petrels that feed on small plankton, are more abundant in the western and central than in the eastern Aleutians (Byrd et al. 2005). In contrast, species, such as tufted puffins Fratercula cirrhata, that forage on larger prey, have bigger colonies in the eastern Aleutians (Hunt \& Stabeno 2005). The respective influence of the neritic Alaska Coastal Current in the eastern passes and the more oceanic Alaskan Stream in the central Aleutians is believed to be responsible for this pattern (Coyle 2005, Hunt \& Stabeno 2005).

Field methods. We compared the summer and winter at-sea distribution of seabirds around 3 major seabird colonies: Buldir Island $\left(52.35^{\circ} \mathrm{N}, 175.93^{\circ} \mathrm{E}\right)$ in the western Aleutians, Kasatochi Island $\left(52.17^{\circ} \mathrm{N}, 175.51^{\circ} \mathrm{W}\right)$ in the central Aleutians, and Aiktak Island $\left(54.19^{\circ} \mathrm{N}\right.$, $164.89^{\circ} \mathrm{W}$ ) in the eastern Aleutian Islands (Fig. 1). These islands are of similar size, free of introduced predators, support major seabird colonies (Byrd et al. 2005), and are all part of a network of seabird monitoring sites within the Alaska Maritime National Wildlife Refuge.

As part of the Seabird, Marine Mammal, Oceanographic Coordinated Investigation (SMMOCI) project, we conducted ship-based surveys of birds at sea between 1995 and 2003. Each site was visited at least once in summer and winter (Table 1). Seabirds were counted during daylight hours from the flying bridge ( $8 \mathrm{~m}$ above the sea surface) of the MV 'Tiĝla $\hat{x}^{\prime}$ on parallel transects (Fig. 1) using a strip transect method and snapshots for flying birds (Tasker et al. 1984). Transect width was $150 \mathrm{~m}$ to each side (for a combined width of $300 \mathrm{~m}$ ), but was occasionally narrowed if visibility was poor. Two observers, one on each side, counted birds and relayed their observations to a third person who entered the data into a computer. The software attached a time and GPS position to each observation and recorded the vessel's position every $15 \mathrm{~s}$.

Table 1. Year, location, seabird densities (birds $\mathrm{km}^{-2}$ ) of the most common species, and total areas surveyed $\left(\mathrm{km}^{2}\right)$ of summer and winter cruises. Summer cruises were conducted in July and early August; winter cruises, in March. Species are sorted by overall average density. See Appendix 1 for species codes

\begin{tabular}{|c|c|c|c|c|c|c|c|c|c|c|c|c|c|}
\hline \multirow{3}{*}{$\begin{array}{l}\text { Species } \\
\text { code }\end{array}$} & \multicolumn{2}{|c|}{- Buldir -} & \multirow{2}{*}{\multicolumn{5}{|c|}{$\begin{array}{c}\text { Kummer } \\
\text { Susatochi }- \text { Winter }-\end{array}$}} & \multirow{2}{*}{\multicolumn{4}{|c|}{ - Aiktak }} & \multirow{2}{*}{\multicolumn{2}{|c|}{ Wint }} \\
\hline & Summer & Winter & & & & & & & & & & & \\
\hline & 1998 & 1998 & 1996 & 1997 & 2003 & 1998 & 1999 & 1995 & 1996 & 1998 & 1997 & 1998 & 1999 \\
\hline \multicolumn{14}{|l|}{ Density } \\
\hline CRAU & 18.0 & 0.6 & 111.0 & 102.3 & 35.6 & 0.0 & 0.0 & 0.0 & 0.0 & 0.0 & 217.1 & 168.4 & 187.3 \\
\hline LEAU & 10.7 & 0.9 & 11.2 & 444.3 & 27.8 & 0.3 & 0.0 & 0.0 & 0.0 & 0.1 & 0.0 & 0.0 & 0.0 \\
\hline WHAU & 10.8 & 24.2 & 9.0 & 18.9 & 26.7 & 1.5 & 2.8 & 13.5 & 4.5 & 5.9 & 248.7 & 63.7 & 92.2 \\
\hline STSH & 82.4 & 0.1 & 17.5 & 0.1 & 2.8 & 0.0 & 0.0 & 132.3 & 347.2 & 4.9 & 0.0 & 0.0 & 0.0 \\
\hline NOFU & 17.5 & 3.0 & 2.7 & 74.7 & 23.9 & 22.1 & 69.1 & 63.2 & 48.0 & 17.2 & 0.4 & 0.4 & 24.8 \\
\hline COMU & 0.5 & 1.0 & 0.6 & 0.7 & 0.3 & 0.6 & 0.3 & 4.1 & 4.1 & 5.5 & 131.5 & 37.9 & 139.2 \\
\hline TUPU & 14.2 & 0.0 & 8.7 & 6.3 & 10.8 & 0.0 & 0.0 & 70.2 & 53.9 & 45.7 & 0.0 & 0.0 & 0.0 \\
\hline TBMU & 6.5 & 0.1 & 1.6 & 1.5 & 1.1 & 0.0 & 0.0 & 0.3 & 0.2 & 0.9 & 70.9 & 16.6 & 66.2 \\
\hline GWGU & 4.5 & 12.6 & 2.9 & 1.8 & 2.6 & 7.7 & 21.2 & 3.2 & 2.7 & 2.3 & 3.7 & 3.0 & 6.6 \\
\hline ANMU & 0.6 & 0.0 & 0.0 & 1.7 & 0.0 & 0.0 & 0.0 & 9.9 & 16.2 & 15.5 & 0.0 & 0.0 & 0.6 \\
\hline FTSP & 17.1 & 0.0 & 0.2 & 5.7 & 0.1 & 0.0 & 0.0 & 0.2 & 1.5 & 3.9 & 0.0 & 0.0 & 0.0 \\
\hline BLKI & 7.1 & 0.8 & 0.1 & 0.5 & 0.2 & 1.4 & 4.2 & 0.7 & 0.0 & 0.0 & 2.9 & 2.3 & 9.5 \\
\hline LAAL & 3.1 & 0.7 & 1.1 & 0.5 & 0.4 & 0.0 & 7.3 & 0.0 & 0.0 & 0.6 & 0.0 & 0.1 & 0.8 \\
\hline PAAU & 7.3 & 0.0 & 1.1 & 1.2 & 2.4 & 0.0 & 0.0 & 0.1 & 0.0 & 0.0 & 1.2 & 0.0 & 0.0 \\
\hline PECO & 0.0 & 0.8 & 0.0 & 0.1 & 0.1 & 2.0 & 0.3 & 0.0 & 0.0 & 0.0 & 1.3 & 1.0 & 4.4 \\
\hline HOPU & 3.0 & 0.0 & 0.1 & 0.2 & 0.5 & 0.1 & 0.0 & 0.8 & 0.7 & 1.6 & 0.0 & 0.0 & 0.2 \\
\hline REPH & 0.3 & 0.0 & 0.1 & 0.0 & 3.5 & 0.0 & 0.0 & 2.0 & 0.0 & 0.0 & 0.0 & 0.0 & 0.0 \\
\hline CAAU & 0.0 & 0.0 & 0.0 & 0.0 & 3.9 & 0.0 & 0.0 & 0.3 & 0.0 & 0.0 & 0.0 & 0.0 & 0.0 \\
\hline RFCO & 0.1 & 0.4 & 0.0 & 0.0 & 0.0 & 0.7 & 0.1 & 0.0 & 0.0 & 0.1 & 0.3 & 0.4 & 1.4 \\
\hline SOSH & 0.0 & 0.0 & 0.0 & 0.0 & 0.0 & 0.0 & 0.0 & 1.5 & 3.9 & 0.0 & 0.0 & 0.0 & 0.0 \\
\hline Area & 59.2 & 42.8 & 52.9 & 48.0 & 47.5 & 52.7 & 27.7 & 128.1 & 29.7 & 59.3 & 52.3 & 50.7 & 27.0 \\
\hline
\end{tabular}


Data analysis. Individual observations were binned into $3 \mathrm{~km}$-long sections. At $10 \mathrm{knots}, 3 \mathrm{~km}$ is covered in close to $10 \mathrm{~min}$, which is a standard interval in pelagic seabird surveys (Tasker et al. 1984). Section length was calculated along the trackline, allowing for curvilinear sections. To avoid spuriously high density estimates, terminal sections shorter than $1.5 \mathrm{~km}$ were added to the previous $3 \mathrm{~km}$ section. To keep surveys comparable, we restricted the analysis to the smallest area covered by all surveys (a circle of 10 nautical miles [18.5 km] radius around each site).

Bird numbers were converted to bird biomass, using mass data from del Hoyo et al. $(1992,1996)$. This was necessary to compare individuals of different species on the same scale and has the advantage of being closely linked to metabolic rate. We used the mean where several mass values were available. Finally, we calculated average bird biomass density $\left(\mathrm{kg} \mathrm{km}^{-2}\right)$ for each species, for each given site and season. To take varying section size into account, we weighted the mean by the section area. Due to the strongly skewed distributions characteristic for avian at-sea density data, ANOVA was not a suitable tool to investigate interannual variability. Instead, we plotted the first major axes of a detrended correspondence analysis for each survey.

Several of the relevant species are difficult to identify in the field to species level under less than ideal conditions. Thus, $9.4 \%$ of birds were identified to genus level only. We assumed unidentified individuals of similar and common species pairs to be distributed between the species pairs at the same ratios as the identified birds at each site and season, and allocated them to the identified birds at the appropriate ratio. We excluded species that were recorded, but do not forage in the ocean, such as waders or raptors. This left 35 species in the dataset (see Appendix 1). We assigned each species to 1 of 3 foraging guilds (planktivore, piscivore, or mixed diets) based on information in 'Birds of North America' accounts (Poole \& Gill 2007) as a guide. We used sources as close to our study sites as possible and considered both direct methods and stable isotope studies. To classify a species, we only considered adult diet. While this can differ from chick diet, the time to fledging is only a small fraction out of the total lifespan for all species considered here.

We were interested in the differences in biological diversity between sites and seasons, so we first determined the species richness (i.e. the number of species) per site and season. We then calculated the species diversity; species diversity also takes the abundance of each species into account. If 2 sites have the same number of species, the site with the more even distribution of species abundances is regarded as more diverse. We used the diversity index Shannon's $H$, which is the negative sum of the product of the proportion of each species and the natural logarithm of that proportion:

$$
H=-\sum_{i=1}^{S} p_{i} \ln p_{i}
$$

where $S$ is the number of species (richness) and $p$ is the proportion of each species' abundance. Shannon's equitability (or evenness) is calculated by:

$$
E_{H}=\frac{H}{H_{\max }}=\frac{H}{\ln S}
$$

Shannon's $H$ can take values from 1 to $\ln S$. Shannon's equitability $E_{H}$ can range from $>0$ (small values indicating dominant species) to 1 (all species at the same abundance).

All $90 \%$ confidence intervals (CI, 0.05 and 0.95 percentiles) were calculated by bootstrapping with 5000 replicates. For the bootstrap, we pooled data from all years and used the $3 \mathrm{~km}$ sections as the sampling unit. Calculations were performed in $\mathrm{R}$ ( $\mathrm{R}$ Development Core Team 2007), with the packages geoR and sp.

\section{RESULTS}

\section{Seabird biomass}

There were significant differences in mean at-sea biomass densities of seabirds (all species combined) among our 3 study areas (non-overlapping confidence intervals; Fig. 2). In both seasons, bird biomass density was highest around Aiktak. In summer, the biomass density of seabirds was higher at Aiktak than at Kasatochi or Buldir (Fig. 2). Mean seabird biomass density greatly decreased from summer to winter in nearshore waters at the western and central Aleutian sites, but not at the eastern site, where we observed a slight increase in biomass density (by

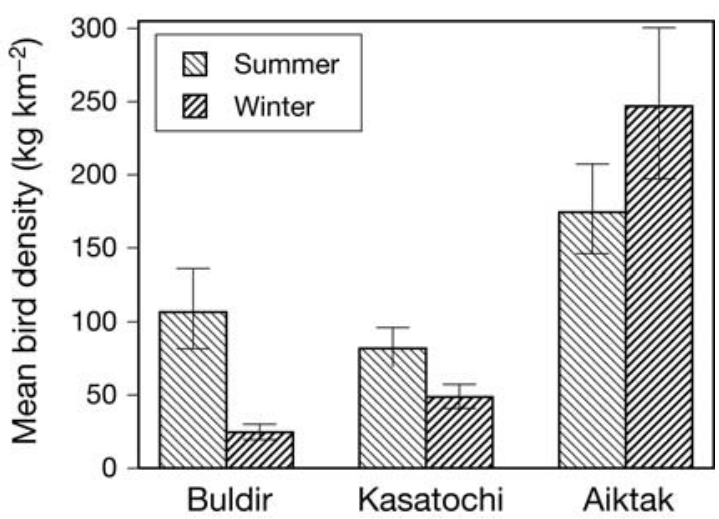

Fig. 2. Average seabird biomass densities by sites and seasons. Error bars are $90 \%$ confidence intervals calculated from 5000 bootstrap replicates 
$41 \%$ reaching $246 \mathrm{~kg} \mathrm{~km}^{-2}$ ). Furthermore, at Aiktak, the winter seabird biomass density was 5 to 10 times greater than the winter densities at the western sites.

\section{Interannual variability}

The large-scale differences in biomass and species composition (see below) between sites and seasons were consistent across years (Table 1). Expressed in the first major axes of a detrended correspondence analysis (eigenvalues 0.70 and 0.31, respectively), observed interannual variation was greater in summer (Aiktak and Kasatochi) than in winter (Fig. 3). While

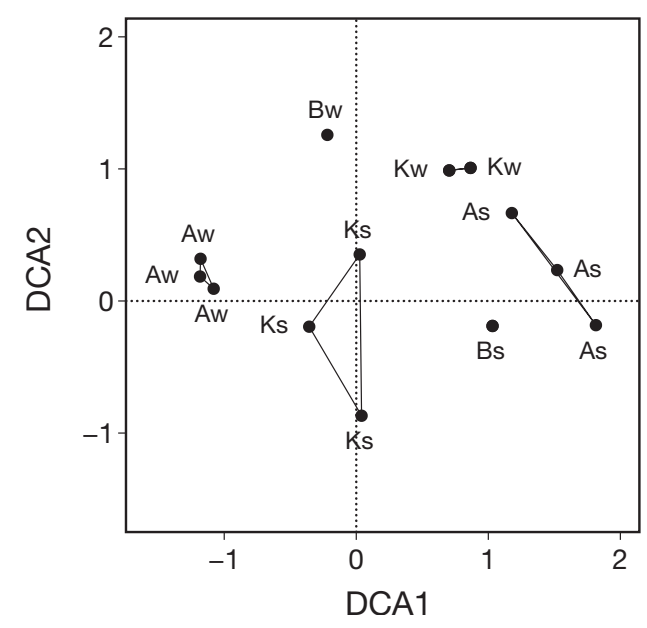

Fig. 3. Detrended correspondence analysis (DCA) of each seabird survey showing interannual and inter-site variation of the first major axes DCA1 and DCA2. B: Buldir; K: Kasatochi; A: Aiktak; s: summer; w: winter. The lines connect surveys at the same site and season, but in different years our sample size was small (up to $3 \mathrm{yr}$ site $^{-1}$ and season $^{-1}$ ), the convex hulls of site-season groups for the 2 major axes did not overlap, but each occupied a distinct space within the space of the first major axes. This indicates that the variations observed between sites and seasons were large in comparison to interannual variation (Fig. 3).

\section{Species composition}

Seasonal changes in biomass were the result of changes in species composition, as well as changes in density. For example, the most significant contributors to combined bird biomass during summer at all sites were migratory species, which were not recorded during winter (Fig. 4). These included short-tailed shearwaters Puffinus tenuirostris (STSH) at Buldir (45\% of total bird biomass) and Aiktak (46\%), and crested auklets Aethia cristatella (CRAU) at Kasatochi (27\%). In summer, tufted puffins (TUPU) were also large contributors to seabird biomass at all sites (8 to $25 \%$ ).

After the northern summer, many species of seabirds (including shearwaters breeding in the Southern Hemisphere) left nearshore waters in the region. While comparatively few birds remained at the western sites during winter, the loss of biomass through the departure of breeding birds and migrants was more than compensated for at Aiktak by the influx of wintering common and thick-billed murres Uria aalge (COMU) and $U$. lomvia (TBMU), respectively, and high numbers of crested auklets (Fig. 4). Two of these species were rare or absent around Aiktak during summer.

There also might have been a local concentration of whiskered auklets Aethia pygmaea (WHAU) near Aik-
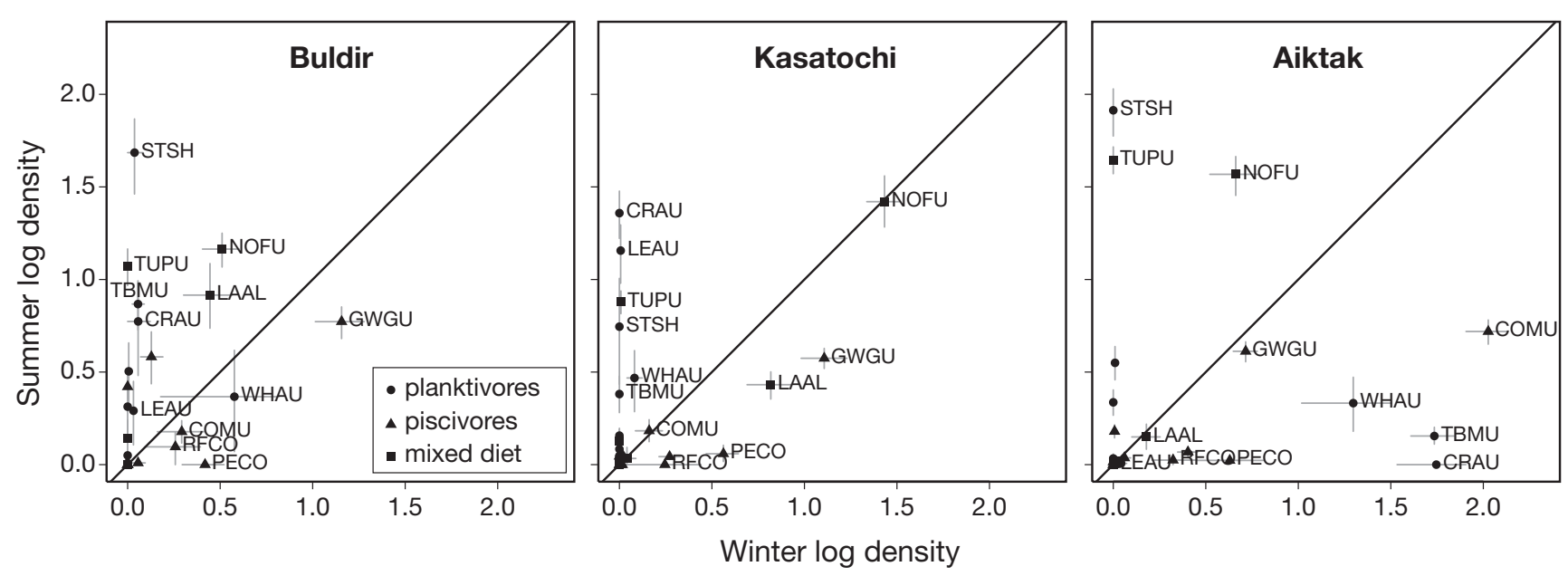

Fig. 4. Comparison of summer and winter bird biomass densities $\left[\log _{10}(\right.$ density +1$\left.)\right]$ within 10 nautical miles of Buldir, Kasatochi, and Aiktak. Species below the diagonal line were more abundant in winter than in summer. Error bars are $90 \%$ confidence intervals based on 5000 bootstrap replicates. Rare species were plotted, but not labeled. See Appendix 1 for species codes 
tak in winter (Fig. 4). Murres and crested auklets were the most important species around Aiktak in winter (43 and $22 \%$ of total bird biomass, respectively), whereas the primary species present at Kasatochi and Buldir in winter were glaucous-winged gulls Larus glaucescens (GWGU, 24 and $55 \%$ ) and northern fulmars Fulmarus glacialis (NOFU, 1 and $54 \%$ ). Whiskered auklets were the only species of Aethia auklets that remained at Kasatochi and Buldir from the large summer multispecies assemblage of auklets. At all sites, glaucouswinged gulls increased during winter.

To examine the seasonal patterns of abundance by different foraging guilds, we plotted the log ratio of winter to summer densities of each species (Fig. 5). Since the summer-winter patterns at Buldir and Kasatochi were similar to each other, and differed from the pattern at Aiktak, we averaged seabird densities at Buldir and Kasatochi (hereafter referred to as 'western sites').

Two marked patterns were apparent (Figs. 4 \& 5): (1) all species that increased at the western sites in winter (above the horizontal dashed line) also increased at Aiktak (right of the vertical dashed line) and (2) all of these species were piscivorous. The only planktivorous

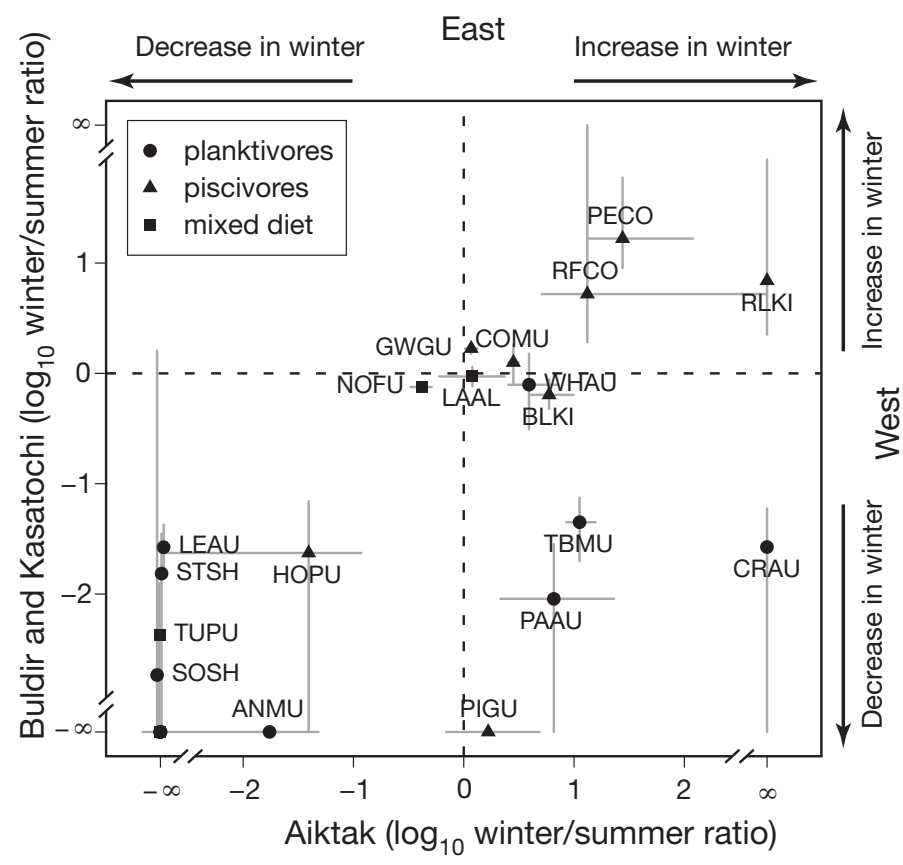

Fig. 5. Ratios of winter to summer abundance of seabirds around Buldir and Kasatochi (western and central Aleutians, combined) and Aiktak (eastern Aleutians, Unimak Pass). Species in the upper right and lower left quadrants show the same seasonal trends at both eastern and western sites (upper right quadrant: winter increase; lower left quadrant: winter decrease), species in the upper left and lower right quadrants show opposing seasonal trends between sites. $\infty$ values: species absent during summer; $-\infty$ values: species absent during winter. Error bars are $90 \%$ confidence intervals based on 5000 bootstrap replicates. See Appendix 1 for species codes species encountered at the western sites at densities comparable to their summer densities was the whiskered auklet. By contrast, the lower right quadrant of Fig. 5 was almost entirely populated by planktivorous species (the only exceptions are close to the edges, their $90 \%$ CI reaching out of the quadrant). Of these, crested auklet, thick-billed murre, and parakeet auklet Aethia psittacula (PAAU) were the farthest from the dashed lines, indicating that these species showed the strongest opposing seasonal trends between the eastern and central/western sites.

At Aiktak, short-tailed shearwaters in summer, and murres and crested auklets in winter, aggregated over similar bathymetric features on the side of a sill to the north of the island (Fig. 6a-c). We found murres also over the sill itself. By comparison, a common piscivorous species (glaucous-winged gull; Fig. 6d) was found in deeper water, and a species feeding on squid and fish (tufted puffin; Fig. 6e; diet in Unimak Pass according to LGL Alaska Research Associates, Inc. 1991) in shallower waters, than short-tailed shearwaters or crested auklets.

\section{Diversity}

Species diversity reflected a similar pattern in which the seasonal changes at Aiktak differed from that observed at the other locations (Table 2). While species richness declined from summer to winter at all sites (by 15 to $18 \%$ ), Aiktak (which had lower summer diversity than the other sites) was the only site at which the diversity did not decrease from summer to winter. At Aiktak, the loss of richness was compensated by a near doubling of species equitability $E_{H}(0.048$ to 0.093$)$, which was not reflected at the other sites. The diversity at Aiktak in summer was similar to the diversity at the other sites and seasons, because the lowest equitability observed was offset by the greatest species richness within the set.

\section{DISCUSSION}

We found remarkable differences in seasonal patterns of species composition of the seabird communities in the nearshore marine waters of an eastern Aleutian site and sites in the central and western Aleutians. These patterns were stable across several years. In summer, seabird biomass density and species richness were highest at the eastern site. From summer to winter, seabird biomass density and richness declined (sometimes dramatically) in the 2 western sites, while biomass density increased at the eastern site (Fig. 2, Table 2). 

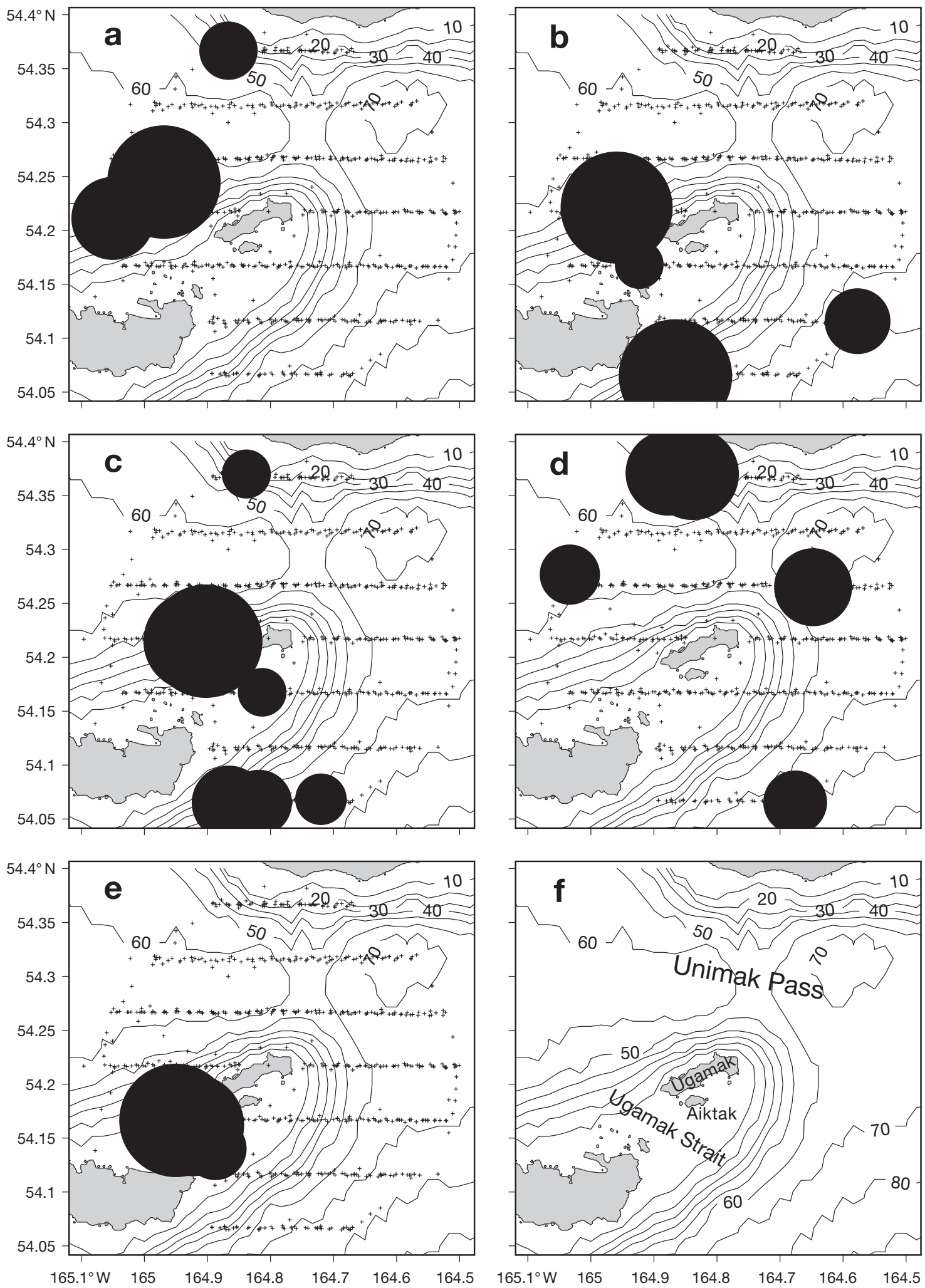

Fig. 6. (a) Puffinus tenuirostris, (b) Aethia cristatella, (c) Uria lomvia, (d) Larus glaucescens, and (e) Fratercula cirrhata distribution around Aiktak Island. See Panel f for place names. Summer distribution is shown for P. tenuirostris and F. cirrhata; winter distribution, for all other species. Dots represent relative densities for each species, i.e. the largest dot matches the greatest density measured for each species. Small crosses indicate survey effort, showing where the species was not recorded 
Table 2. Seabird species richness ( $S$, number of species; number of species breeding on the islands in parentheses), diversity, and equitability ( $E_{H}$, evenness) in summer and winter. Shannon's $H$ and equitability $E_{H}$ are displayed with the respective $90 \%$ confidence intervals, calculated from 5000 bootstrap replicates

\begin{tabular}{|llcclll|}
\hline Site & Season & $S$ & \multicolumn{2}{l}{$H$} & \multicolumn{2}{l|}{$E_{H}$} \\
\hline Buldir & Summer & $23(20)$ & 1.95 & $1.71-2.15$ & 0.085 & $0.077-0.101$ \\
& Winter & 15 & 1.60 & $1.33-1.78$ & 0.107 & $0.093-0.130$ \\
\multirow{3}{*}{ Kasatochi } & Summer & $24(13)$ & 1.90 & $1.77-1.99$ & 0.079 & $0.075-0.088$ \\
& Winter & 14 & 1.32 & $1.21-1.40$ & 0.094 & $0.089-0.114$ \\
Aiktak & Summer & $29(12)$ & 1.40 & $1.31-1.47$ & 0.048 & $0.046-0.055$ \\
& Winter & 16 & 1.49 & $1.39-1.58$ & 0.093 & $0.088-0.106$ \\
\hline
\end{tabular}

These patterns are consistent with Samalga Pass marking a major ecological boundary (Hunt \& Stabeno 2005). There were differences in the within-season species composition between Buldir and Kasatochi (Fig. 3), as can be expected when dividing the Aleutian Archipelago into 3 eco-zones (Piatt \& Springer 2007). However, these differences between the 2 western sites were small compared to those found between the western site and the eastern sites. The broad inter-seasonal patterns in bird biomass density, dominant foraging guilds and diversity are shared between the 2 western sites and contrast sharply with the eastern site.

\section{Auklets and shearwaters}

At Aiktak Island, the close spatial match in the location of crested auklet and murre aggregations in winter and short-tailed shearwater flocks in summer (Fig. 6) suggests that these species exploit the same food source, albeit at different seasons, and that similar mechanisms concentrate the prey in near-surface waters, where they are available to the birds. Thysanoessa euphausiids have been identified as an important prey of short-tailed shearwaters, murres, and both crested and whiskered auklets, including in the Unimak Pass region in both summer and winter (LGL Alaska Research Associates, Inc. 1991, Jahncke et al. 2005). Presumably, tidal fluxes advect euphausiids to the surface when passing over the sill in Ugamak Strait (Fig. 6f), a mechanism similar to that found at the Delarof Islands (Hunt et al. 1998) and at the Pribilof Islands (Coyle et al. 1992).

No least and only a few crested auklets breed in the Aleutians east of Koniuji Island $(30 \mathrm{~km}$ east of Kasatochi Island; Stephensen \& Irons 2003, Byrd et al. 2005). Stephensen \& Irons (2003) suggested that this absence of breeding auklets might be due to a lack of breeding sites created through recent volcanic activity. However, auklets can breed successfully in cliff crevices and under beach boulders, so there is appar- ently suitable nesting habitat in the eastern Aleutians. For example, least and crested auklets often share breeding habitat with whiskered auklets (Byrd \& Williams 1993), which are abundant throughout the eastern Aleutians (Williams et al. 2003).

Least auklets specialize on oceanic Neocalanus copepods (Russell et al. 1999), which might not be available in sufficient densities in the eastern Aleutians (Coyle 2005). Crested auklets, however, prey more on larger euphausiids (Russell et al. 1999), which are abundant in the eastern Aleutians (LGL Alaska Research Associates, Inc. 1991, Coyle 2005). While short-tailed shearwaters are found throughout the Aleutians, mega-flocks numbering into the millions have only been documented from the eastern Aleutians (Gibson \& Byrd 2007), where the species feeds largely on euphausiids (Jahncke et al. 2005). Shearwater feeding behavior is disruptive to other species (Hoffman et al. 1981), and thus interference competition from shearwaters could be a contributor to the lack of crested auklet colonies in the eastern Aleutians. Crested auklets occupy this foraging niche in the winter, when short-tailed shearwaters breed in the Southern Hemisphere.

Hunt et al. (2005) described the seasonal patterns of birds from the Gulf of Alaska, where some of the currents affecting Aleutian waters originate; patterns quite similar to what we observed in the Unimak Pass area, with seabird biomass density higher in winter than during summer. The cause of the higher winter density in the Gulf of Alaska was the influx of seaducks. Although we also noted a winter increase of seaducks around Aiktak (as did LGL Alaska Research Associates, Inc. 1991), this group of birds did not contribute much to the overall bird biomass there (Fig. 4). Also, our transects might have been too far offshore to detect the main concentrations of ducks in winter. Similar to our results at Aiktak, the abundance of murres and planktivorous auklets over the Gulf of Alaska basin increased greatly in winter (Hunt et al. 2005).

\section{Euphausiids at Unimak Pass}

Within the Unimak Pass area around Aiktak, Thysanoessa euphausiids were the main prey of murres and auklets in winter (LGL Alaska Research Associates, Inc. 1991). In contrast to copepods that diapause at depth in winter (Miller \& Clemons 1988), in the Unimak Pass region, euphausiids remain active in nearsurface waters, and dominate the mesozooplankton 
fauna in winter (LGL Alaska Research Associates, Inc. 1991). Euphausiids are thus available to seabirds around Unimak Pass throughout the year. Given the strong contrast in seasonal trends of planktivorous seabirds between the central and western sites compared to the trends at Aiktak, we postulate that, in winter, euphausiids do not occur in the central and western sites in densities as high as those at Aiktak.

It is not known why there is this apparent east-west difference in the winter availability of euphausiids to seabirds in the Aleutians. One possible hypothesis is that the euphausiids in the Unimak Pass region are advected there from the Aleutian North Slope Current, and thus probably originate in the Gulf of Alaska, having been carried to the Bering Sea by the Alaskan Stream as it flows northward through Amukta and Amchitka Passes (Stabeno et al. 2005). Such a scenario would help to explain why most of the large aggregations of foraging shearwaters in summer and of murres and crested auklets in winter are on the north side of the eastern Aleutian Archipelago (LGL Alaska Research Associates, Inc. 1991, Jahncke et al. 2005, Ladd et al. 2005). It is also consistent with the observation that, east of Samalga Pass, the diets of Pacific Ocean perch Sebastes alutus, walleye pollock Theragra chalcogramma and Atka mackerel Pleurogrammus monopterygius are dominated by euphausiids (50 to $90 \%$ occurrence), whereas, west of Samalga Pass, euphausiids occur less frequently in the diets of these fish $(<50 \%)$ and copepods and myctophids become the dominant prey items (Logerwell et al. 2005).

\section{Foraging guilds}

In the western and central Aleutian Islands, all of the seabird species that occurred at significantly higher biomass densities in winter than in summer were piscivores (Fig. 5). The classification of seabirds into planktivores and piscivores is somewhat artificial. Many species can switch their diet, e.g. from predominantly plankton to fish. However, the most extreme cases driving the pattern in Fig. 5 are relatively specialized foragers (piscivores: cormorants, gulls; planktivores: crested auklet, parakeet auklet). Given this gradient of piscivores (high western $\log _{10}$ winter/summer ratio) to planktivores (low western $\log _{10}$ winter/summer ratio) we can examine where species pairs with a more intermediate diet are found.

Bill morphology and actual diet samples suggest that thick-billed murres Uria lomvia are more planktivorous than common murres $U$. aalge (Ainley et al. 2002), even though both fish and invertebrates have been found as the predominant diet in each murre species (Ainley et al. 2002). In our study, the seasonal dis- tribution patterns of thick-billed murres match those of other planktivores, but those of common murres have closer resemblance with species of an intermediate diet (Fig. 5), suggesting a dietary specialization as predicted from bill morphology.

Whiskered auklets Aethia pygmaea were the only Aethia auklet species and the only plankton specialist to remain in the western and central Aleutians in winter at densities similar to those found during summer (Fig. 5). Whiskered auklets differ from their congeners in remaining near the breeding sites throughout the year and roosting on land at night (Byrd \& Williams 1993). During summer, their diet is more diverse (greater Shannon's $H$ ) than that of other Aethia auklets (G. Fraser pers. comm.). The species might therefore be more flexible than its congeners in exploiting different resources when their preferred prey becomes scarce. This dietary flexibility might allow the species to occupy a much wider range within the Aleutian Archipelago than least and crested auklets (A. pusilla and A. cristatella, respectively; Williams et al. 2003). In winter, whiskered auklets in the Unimak Pass region consumed mainly euphausiids (LGL Alaska Research Associates, Inc. 1991). It is unknown what prey they use in winter farther west in the Aleutians, where whiskered auklets maintain high winter densities even though euphausiids appear to be less common.

\section{CONCLUSIONS}

We found that at all sites, the main piscivorous seabirds increased in winter, whereas, with the exception of whiskered auklets, planktivorous seabird species declined at the sites in the central and western Aleutian Islands. In contrast, at the eastern Aleutian site close to Unimak Pass, planktivorous seabird biomass increased significantly, despite the departure of summer visitors such as short-tailed shearwaters. From this we infer that the large copepod species and euphausiids that support most central and western Aleutian planktivores in summer were not available in winter. In contrast, euphausiids apparently remain abundant in the vicinity of Unimak Pass all winter, supporting a large seabird biomass. Existing data on winter diets and availability of zooplankton in the central and western Aleutians are inadequate to address how whiskered auklets meet their trophic requirement in winter there.

Euphausiids are an important component of the diets of many commercially important fish species, including walleye pollock. The presence of high numbers of wintering, euphausiid-dependent seabirds in the vicinity of the north end of Unimak Pass suggests that concentrations of euphausiids there must be extraordinarily high in winter as well as in summer. There is a 
need to understand the mechanisms responsible for these large aggregations of euphausiids and the environmental conditions that might affect their availability to the fish, seabirds, and marine mammals that depend on them.

Acknowledgements. We thank R. Merrick and K. Chumbley from the National Marine Mammal Lab for sharing their data from the winter cruises that were an essential component of the present paper. D. Dragoo and J. Williams did much of the heavy lifting in the field to keep this project running. We extend our appreciation to the captain and crew of the MV 'Tiĝlax̂' for making this vessel a safe and dependable working platform. D. Dragoo, K. Morgan, H. Renner, and 4 anonymous reviewers provided comments on earlier drafts, which improved this manuscript. Funding came from the U.S. Geological Survey and Alaska Maritime National Wildlife Refuge. M.R. thanks the COASST lab for their hospitality and J. Parrish for her advice and help in numerous ways.

\section{LITERATURE CITED}

Ainley DG, Nettleship DN, Carter HR, Storey AE (2002) Common murre (Uria aalge). In: Poole A, Gill F (eds) Birds of North America, No. 666. The Birds of North America, Inc., Philadelphia, PA, p 1-44

Byrd GV, Williams JC (1993) Whiskered auklet (Aethia pygmaea). In: Poole A, Gill F (eds) The birds of North America, No 76. The Academy of Natural Sciences of Philadelphia and the American Ornithologists' Union, Washington, DC, p 1-12

Byrd GV, Renner HM, Renner M (2005) Distribution patterns and population trends of breeding seabirds in the Aleutian Islands. Fish Oceanogr 14(Suppl 1):139-159

> Coyle KO (2005) Zooplankton distribution, abundance and biomass relative to water masses in eastern and central Aleutian Island passes. Fish Oceanogr 14(Suppl 1):77-92

Coyle KO, Pinchuk A (2005) Seasonal cross-shelf distribution of major zooplankton taxa on the northern Gulf of Alaska shelf relative to water mass properties, species depth preferences and vertical migration behaviour. Deep-Sea Res II 52:217-245

> Coyle KO, Hunt GL Jr, Decker MB, Weingartner TJ (1992) Murre foraging, epibenthic sound scattering and tidal advection over a shoal near St. George Island, Bering Sea. Mar Ecol Prog Ser 83:1-14

del Hoyo J, Elliott A, Sargatal J (eds) (1992) Handbook of the birds of the world, Vol 1. Ostrich to ducks. Lynx Edicions, Barcelona

del Hoyo J, Elliott A, Sargatal J (eds) (1996) Handbook of the birds of the world, Vol 3. Hoatzin to auks. Lynx Edicions, Barcelona

Gibson DD, Byrd GV (2007) Birds of the Aleutian Islands, Alaska. In: Causey D (ed) Series in ornithology, No. 1. Nuttall Ornithological Club and American Ornithologists' Union, Cambridge, MA, p 1-351

Hoffman W, Heinemann D, Wiens JA (1981) The ecology of seabird feeding flocks in Alaska. Auk 98:437-456

$>$ Hunt GL Jr, Stabeno PJ (2005) Oceanography and ecology of the Aleutian Archipelago: spatial and temporal variation. Fish Oceanogr 14(Suppl 1):292-306

Hunt GL Jr, Russell RW, Coyle KO, Weingartner T (1998) Comparative foraging ecology of planktivorous auklets in relation to ocean physics and prey availability. Mar Ecol Prog Ser 167:241-259
Hunt GL Jr, Drew GS, Jahncke J, Piatt JF (2005) Prey consumption and energy transfer by marine birds in the Gulf of Alaska. Deep-Sea Res II 52:781-797

Jahncke J, Coyle KO, Hunt GL Jr (2005) Seabird distribution, abundance and diets in the eastern and central Aleutian Islands. Fish Oceanogr 14(Suppl 1):160-177

Ladd C, Jahncke J, Hunt GL Jr, Coyle KO, Stabeno PJ (2005) Hydrographic features and seabird foraging in Aleutian passes. Fish Oceanogr 14(Suppl 1):178-195

LGL Alaska Research Associates, Inc. (1991) Marine birds and mammals of the Unimak Pass Area: abundance, habitat use and vulnerability. MMS Contract 14-35-000130564 (formerly NOAA/OCSEAP RU 689), OCS Study MMS 91-0038, 4175 Tudor Centre Drive, Suite 101, Anchorage, AK 99508

Logerwell EA, Aydin K, Barbeaux S, Brown E, and others (2005) Geographic patterns in the demersal ichthyofauna of the Aleutian Islands. Fish Oceanogr 14(Suppl 1): 93-112

Luchin VA, Menovshchikov VA, Lavrentiev VM, Reed RK (1999) Thermohaline structure and water masses in the Bering Sea. In: Loughlin TR, Ohtani K (eds) Dynamics of the Bering Sea. University of Alaska Sea Grant, AK-SG99-03, Fairbanks, AK, p 61-91

Miller CB, Clemons MJ (1988) Revised life history analysis for large grazing copepods in the subarctic Pacific Ocean. Prog Oceanogr 20:293-313

Mordy CW, Stabeno PJ, Ladd C, Zeeman S, Wisegarver DP, Salo SA, Hunt GL Jr (2005) Nutrients and primary production along the eastern Aleutian Island Archipelago. Fish Oceanogr 14(Suppl 1):55-76

Nakata K, Doi T, Taguchi K, Aoki S (2004) Characterization of ocean productivity using a new physical-biological coupled ocean model. In: Shiyomi M, Kawahata H, Hiroshi K, Tsuda A, Awaya Y (eds) Global environmental change in the ocean and on land. Terrapub, Tokyo, p 1-44

Overland JE, Spillane MC, Hurlburt HE, Wallcraft AJ (1994) A numerical study of the circulation of the Bering Sea basin and exchange with the North Pacific Ocean. J Phys Oceanogr 24:736-758

Piatt JF, Springer AM (2007) Marine ecoregions of Alaska. In: Spies RB (ed) Long-term ecological change in the northern Gulf of Alaska. Elsevier, Amsterdam, p 522-526

Poole A, Gill F (eds) (2007) The birds of North America online. Cornell Lab of Ornithology and American Ornithologists' Union. Available at http://bna.birds.cornell.edu/, accessed 3 April 2007

R Development Core Team (2007) R: a language and environment for statistical computing. R Foundation for Statistical Computing, Vienna. Available at www.R-project.org, accessed 27 April 2007

Reed RK, Stabeno PJ (1999) The Aleutian North Slope Current. In: Loughlin TR, Ohtani K (eds) Dynamics of the Bering Sea. University of Alaska Sea Grant, AK-SG-99-03, Fairbanks, AK, p 177-191

Russell RW, Harrison NM, Hunt GL Jr (1999) Foraging at a front: hydrography, zooplankton, and avian planktivory in the northern Bering Sea. Mar Ecol Prog Ser 182:77-93

Stabeno PJ, Schumacher JD, Ohtani K (1999) The physical oceanography of the Bering Sea. In: Loughlin TR, Ohtani $\mathrm{K}$ (eds) Dynamics of the Bering Sea. University of Alaska Sea Grant, AK-SG-99-03, Fairbanks, AK, p 1-28

> Stabeno PJ, Reed R, Napp JM (2002) Transport through Unimak Pass, Alaska. Deep-Sea Res 49(Part II):5919-5930

Stabeno PJ, Kachel DG, Kachel N, Sullivan ME (2005) Observations from moorings in the Aleutian passes: temperature, salinity and transport. Fish Oceanogr 14(Suppl 1):39-54 
Stephensen SW, Irons DB (2003) Comparison of colonial breeding seabirds in the eastern Bering Sea and Gulf of Alaska. Mar Ornithol 31:167-173

Tanasichuk RW (1999) Interannual variation in the availability and utilization of euphausiids as prey for Pacific hake (Merluccius productus) along the south-west coast of Vancouver Island. Fish Oceanogr 8:150-156
Tasker ML, Jones PH, Dixon T, Blake BF (1984) Counting seabirds at sea from ships: a review of methods employed and a suggestion for a standardized approach. Auk 101: $567-577$

Williams JC, Byrd GV, Konyukhov NB (2003) Whiskered auklet Aethia pygmaea, foxes, humans and how to right a wrong. Mar Ornithol 31:175-180

Appendix 1. Bird species abbreviations (where used; in systematic order), Latin and common names, and average mass values of species encountered during the surveys (mass values from del Hoyo et al. 1992, 1996)

\begin{tabular}{|c|c|c|c|}
\hline Code & Latin name & Common name & $\begin{array}{l}\text { Mass } \\
(\mathrm{g})\end{array}$ \\
\hline & Phoebastria nigripes & Black-footed albatross & 3300 \\
\hline LAAL & Phoebastria immutabilis & Laysan albatross & 2550 \\
\hline NOFU & Fulmarus glacialis & Northern fulmar & 768 \\
\hline $\mathrm{SOSH}$ & Puffinus griseus & Sooty shearwater & 814 \\
\hline STSH & $\begin{array}{l}\text { Puffinus tenuirostris } \\
\text { Pterodroma inexpectata }\end{array}$ & $\begin{array}{l}\text { Short-tailed shearwater } \\
\text { Mottled petrel }\end{array}$ & $\begin{array}{l}640 \\
344\end{array}$ \\
\hline FTSP & $\begin{array}{l}\text { Oceanodroma furcata } \\
\text { Oceanodroma leucorhoa } \\
\text { Phalacrocorax auritus }\end{array}$ & $\begin{array}{l}\text { Fork-tailed storm-petrel } \\
\text { Leach's storm-petrel } \\
\text { Double-crested cormorant }\end{array}$ & $\begin{array}{r}59 \\
45 \\
1885\end{array}$ \\
\hline PECO & Phalacrocorax pelagicus & Pelagic cormorant & 1956 \\
\hline RFCO & $\begin{array}{l}\text { Phalacrocorax urile } \\
\text { Histrionicus histrionicus } \\
\text { Somateria mollissima }\end{array}$ & $\begin{array}{l}\text { Red-faced cormorant } \\
\text { Harlequin duck } \\
\text { Common eider }\end{array}$ & $\begin{array}{r}2098 \\
625 \\
1980\end{array}$ \\
\hline REPH & $\begin{array}{l}\text { Phalaropus fulicarius } \\
\text { Phalaropus lobatus } \\
\text { Stercorarius pomarinus } \\
\text { Stercorarius longicaudus } \\
\text { Larus hyperboreus }\end{array}$ & $\begin{array}{l}\text { Red phalarope } \\
\text { Red-necked phalarope } \\
\text { Pomarine jaeger } \\
\text { Long-tailed jaeger } \\
\text { Glaucous gull }\end{array}$ & $\begin{array}{r}57 \\
35 \\
750 \\
270 \\
1445\end{array}$ \\
\hline GWGU & Larus glaucescens & Glaucous-winged gull & 1075 \\
\hline BLKI & $\begin{array}{l}\text { Rissa tridactyla } \\
\text { Rissa brevirostris } \\
\text { Xema sabini }\end{array}$ & $\begin{array}{l}\text { Black-legged kittiwake } \\
\text { Red-legged kittiwake } \\
\text { Sabine's gull }\end{array}$ & $\begin{array}{l}408 \\
395 \\
180\end{array}$ \\
\hline COMU & Uria aalge & Common murre & 1000 \\
\hline TBMU & Uria lomvia & Thick-billed murre & 1000 \\
\hline PIGU & $\begin{array}{l}\text { Cepphus columba } \\
\text { Brachyramphus marmoratus }\end{array}$ & $\begin{array}{l}\text { Pigeon guillemot } \\
\text { Marbled murrelet }\end{array}$ & $\begin{array}{l}500 \\
220\end{array}$ \\
\hline ANMU & Synthliboramphus antiquus & Ancient murrelet & 206 \\
\hline CAAU & Ptychoramphus aleuticus & Cassin's auklet & 175 \\
\hline PAAU & Aethia psittacula & Parakeet auklet & 297 \\
\hline CRAU & Aethia cristatella & Crested auklet & 260 \\
\hline LEAU & Aethia pusilla & Least auklet & 85 \\
\hline WHAU & $\begin{array}{l}\text { Aethia pygmaea } \\
\text { Cerorhinca monocerata }\end{array}$ & $\begin{array}{l}\text { Whiskered auklet } \\
\text { Rhinoceros auklet }\end{array}$ & $\begin{array}{l}116 \\
533\end{array}$ \\
\hline HOPU & Fratercula corniculata & Horned puffin & 532 \\
\hline TUPU & Fratercula cirrhata & Tufted puffin & 773 \\
\hline
\end{tabular}

Editorial responsibility: Otto Kinne, Oldendorf/Luhe, Germany
Submitted: May 29, 2007; Accepted: November 5, 2007 Proofs received from author(s): March 21, 2008 